\title{
1991-92 Annual Report
}

Association Of

C O L LE G E

\& RESEARCH

LIBRARIES

\section{ReCRUITMENT TO THE PROFESSION:}

Attracting the best and the brightest 


\section{Mission}

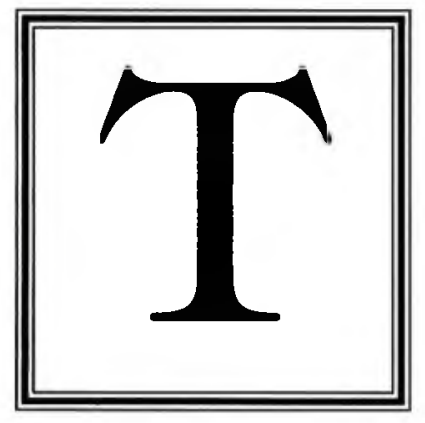

he mission of the Association of College and Research

Libraries (ACRL) is to foster the profession of academic and research librarianship and to enhance the ability of academic and research libraries to serve effectively the library and information needs of current and potential library users. 


\section{Message from the President}

\section{Anne K. Beaubien \\ ACRL's 53RD PRESIDENT}

\section{A}

CRL leaders, members, and staff have every reason to be proud of their efforts during 1991-92. I would like to highlight some of the year's accomplishments and thank those involved for their creativity, enthusiasm, and hard work.

Our Sixth National Conference was held in Salt Lake City on April 12-14 with an attendance of 2,241, including 581 exhibitors. The program was an important forum for discussing a wide range of issues affecting higher education in our information-rich society as well as a financial success.

The year's theme, "Recruitment to the Profession," inspired great enthusiasm and many activities including a project to interest minority undergraduates in the field of library and information science which was funded by the ALA President's Dance Fund. Another major effort was made to update the librarian profiles in two CD-ROM career guidance systems used in career counseling. A large research project was undertaken to validate factors underlying the Strong Vocational Interest Inventory. Thanks to year-end money from ALA, ACRL was able to design

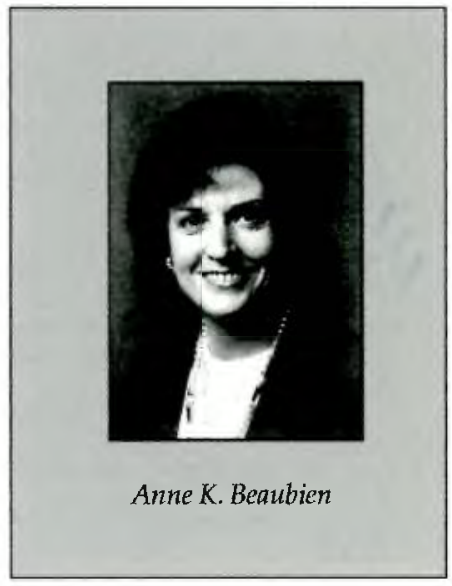
and print a recruitment brochure for wide dissemination. Two sessions at ALA's Annual Conference in San Francisco focused on recruitment, several issues of CERL News carried articles on the theme, and a Task Force on Image is identifying areas in which academic librarianship is misunderstood and will suggest ways to counteract these impressions.

Another ad hoc group, the Task Force on Social Issues, was created to help guide ACRL's response to difficult modern problems. The Task Force on Professional Development submitted a report on what ACRL's role should be in this area. ACRL supported ALA's theme, "Your Right to Know," and collaborated with other units on numerous matters such as accreditation and federal legislation.

As president I attempted to make ACRL's planning process more responsive to the membership and to changes in higher education. The ACRL Board of Directors took part in planning retreats before the Salt Lake City and San Francisco conferences at which they examined the strategic plan, looked at how the planning process can be more effective, and set priorities. Changes will be implemented in the next year that will involve more of the elected leadership in setting priorities and 


\section{Message from the President}

I hope the momentum and changes started will benefit members in the years to come.

These are just a few of ACRL's achievements last year. Feel free to contact me or the ACRL office to learn more about them or about the many other projects I do not have space to mention, none of which would have been successful without the able guidance of executive director Althea Jenkins and her excellent staff or without the energy and dedication of hundreds of members. And thank you all for a wonderful year!

\section{ACRL Membership Statistics}

\begin{tabular}{|c|c|c|c|c|c|}
\hline $\begin{array}{l}\text { ACRL/ } \\
\text { Sections }\end{array}$ & Personal & $\begin{array}{c}\text { Organizational/ } \\
\text { Special }\end{array}$ & $\begin{array}{c}\text { Aug. } 1992 \\
\text { Total }\end{array}$ & $\begin{array}{c}\text { Aug. } 1991 \\
\text { Total }\end{array}$ & $\begin{array}{c}\% \text { increase } \\
\text { decrease }\end{array}$ \\
\hline ACRL & 9,594 & 1,143 & 10,737 & 10,693 & $0.41 \%$ \\
\hline AAS & 418 & 88 & 506 & 486 & $4.12 \%$ \\
\hline AFAS & 185 & 21 & 206 & 192 & $7.29 \%$ \\
\hline ANSS & 492 & 99 & 591 & 581 & $1.72 \%$ \\
\hline ARTS & 840 & 123 & 963 & 886 & $8.69 \%$ \\
\hline BIS & 3,707 & 490 & 4,197 & 4,168 & $0.70 \%$ \\
\hline CJCLS & 857 & 268 & 1,125 & 1,099 & $2.37 \%$ \\
\hline CLS & 1,890 & 366 & 2,256 & 2,207 & $2.22 \%$ \\
\hline EBSS & 1,260 & 236 & 1,496 & 1,535 & $-2.54 \%$ \\
\hline ECLSS & 408 & 28 & 436 & 241 & $80.91 \%$ \\
\hline LPSS & 716 & 123 & 839 & 870 & $-3.56 \%$ \\
\hline RBMS & 1,740 & 214 & 1,954 & 1,953 & $0.50 \%$ \\
\hline SEES & 266 & 69 & 335 & 314 & $6.69 \%$ \\
\hline STS & 1,628 & 279 & 1,907 & 1,876 & $1.65 \%$ \\
\hline ULS & 5,901 & 396 & 6,297 & 6,372 & $-1.18 \%$ \\
\hline WESS & 724 & 70 & 794 & 798 & $-0.50 \%$ \\
\hline wSS & 828 & 76 & 904 & 848 & $6.60 \%$ \\
\hline
\end{tabular}




\title{
Message from the Vice-President
}

\author{
JACQUELYN A. MCCOY \\ Vice-President / President-Elect
}

$\mathbf{T}$

hree rapidly emerging trends in the 1990s-new technologies, a changing economic climate, and increasing diversity in both staff and user populations-are changing the way academic libraries go about serving their faculties, their students, and their communities. Many of us will be, in the very near future, operating the virtual library in which many materials are accessed electronically. Our challenge for this year, and for at least a decade to come, will be to equip both our professional organization and ourselves as librarians to address the issues raised by technological innovations, changing resource allocations, and greater ethnic, racial, academic, and socio-economic diversity among our users and our personnel.

By this report and by separate communications with each ACRL section, chapter, and committee, I am asking these units to provide ACRL with an inventory of innovative ideas as well as recommendations as to how the profession may respond creatively to the multiple challenges outlined above. My concern is that we actively, indeed aggressively, involve our rank-and-file members in helping shape our ACRL organizational

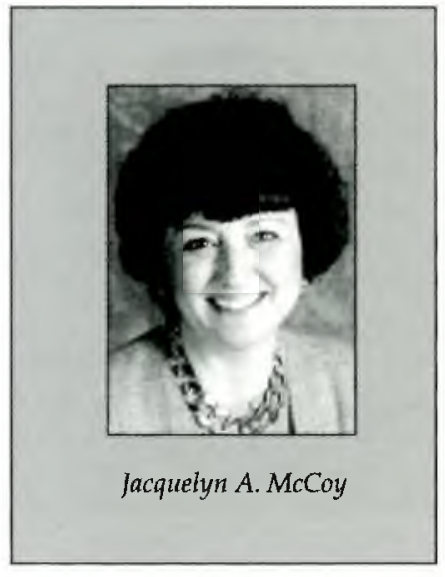
response to these changes. This involvement will, I hope, come through special meetings, workshops, brainstorming sessions and perhaps even written polls of the membership of various ACRL units.

At the national level we will be reviewing the ACRL organizational structure in paralleling the overall ALA organizational evaluation called for by Marilyn Miller, in an effort to provide a more effective and more responsive organization for our members. We will also be assessing the status of our ACRL strategic plan, now entering its sixth year, with a view toward determining if there are ways to clarify, amplify, enhance, or make more effective that critical document.

My challenge to the membership is to suggest very specific and concrete ways which we as a professional organization can help smooth the transition we are making toward the virtual library, can help academic libraries cope creatively with a changing economic climate and reduced resources, and can improve the services we offer to the users and staff who represent such varied backgrounds, interests, and aspirations. My plan is to have presentations of these ideas and recommendations during the ALA Annual Meeting in New Orleans next June. 


\section{Althea H. Jenkins \\ EXECUTIVE DiRECTOR}

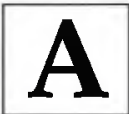

lthough academic libraries faced extraordinary economic and political challenges during the past year, the range of activities of our members continues to demonstrate a commitment and dedication to the library profession. The accomplishments

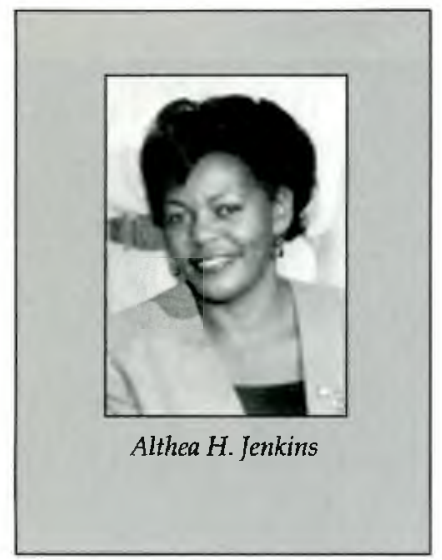
of the ACRL committees, sections, and discussion groups summarized throughout this report demonstrate the enthusiasm members hold for academic librarianship. All who participate recognize that ACRL's diverse membership requires the work of the association primarily to address the complex issues our profession faces. We appreciate the continuing support of ACRL's 11,000 members in meeting our goals.

ACRL was fortunate this year to have the ALA Minority Fellow, Sheila Delacroix, assigned to the division to carry out her work in the area of recruitment in conjunction with the ACRL president's theme.

In addition to the projects supporting the president's theme and the programs detailed on the following pages of this report, ACRL in 1991-92 joined other ALA units and library organizations to:

- Call for a total revision of the ALA Code of Ethics

- Endorse the revised ALA Accreditation Standards

- Support the top three priority action issues of the White House Conference on Library and Information Services

- Endorse the 1991 Improvement of Information Act

- Discourage copyright and use royalties for the ERIC Database.

As I look to the year ahead, it is clear that academic librarians cannot conduct their business in isolation. Changing agendas in higher education, information technology, and education in general present major challenges. Important accomplishments were made in networking and establishing linkages with other library and information-based organizations, higher education associations, and government agencies in FY1992. ACRL leaders, members, and staff will need to continue solidifying and strengthening relationships with associations in the information and higher education professions.

In an era of shrinking resources and escalating demands, the strength of ACRL and the extent to which it is able to impact the information and higher education environment will to a large extent be determined by how well priorities are identified and strategies defined. The ACRL Board of Directors effectively used a retreat to begin a planning process for the $90 \mathrm{~s}$ and beyond. The Board clarified values, stated assumptions, identified strengths and weaknesses, as well as 


\section{Letter from the \\ Executive Director}

internal and external environmental factors that impact ACRL. Following the retreat, the Board was able to set these priorities which will guide program decisions for FY 1993:

1. Communications with members (two-way). ACRL should provide means and media for the sharing of professional ideas, concerns, and activities of academic librarians and libraries and increase communication within ACRL regarding association goals, priorities, and activities.

2. Professional development and learning of our members. ACRL should play a leadership role in providing professional development and learning opportunities for its members.

3. Forum for discussion and debate of issues. ACRL should ensure that appropriate forums exist for thorough discussion and informed debate of key issues facing academic libraries and librarians.

4. Recognition in the higher education community. ACRL should gain recognition within the higher education community as representing the interests of academic librarians and playing a key role in developing relevant national policy.

5. Communication with the higher education community, professional associations. ACRL should increase communication and collaboration with other professional associations within the higher education community to establish partnerships with our academic colleagues in furthering the goals of higher education.

The year brought challenges to ACRL headquarters as well. The ACRL staff was reduced from 12 to 8.5 FTE. My first year was one of learning and discovery. ACRL experienced a decline in revenue for the third consecutive year, while member demands for programs and services continued to increase. The ACRL Sixth National Conference held in Salt Lake City was successful programmatically and

\section{ACRL Staff}

Call us toll free at 1-800-545-2433 ext. XXXX or call us direct at 312-280-XXXX.

- Althea H. Jenkins, Executive Director - 3248

- Cathleen Bourdon, Deputy Executive Director - 2517

- Mary Ellen K. Davis, Editor E Publisher, C\&RL News 2511

- Mary C. Taylor, Program Officer, Publications/Standards/ Statistics - 2515

- Pam Spiegel, Assistant Editor, C\&RL News - 2524

- Merri Monks, Administrative Assistant - 2522

- Reginald Prim, Editorial Assistant, C\&RL News - 2514

- Cynthia Taylor, Administrative Secretary - 2521

- Beverley M. Washington, Administrative Assistant - 2516

- Patricia Sabosik, Editor/Publisher, Choice, 100 Riverview Center, Middletown, CT 06457, (203) 347-6933

Association of College and Research Libraries (ACRL), A Division of the American Library Association, 50 East Huron St., Chicago, IL 60611-2795. fax: $312-280-2520$ financially thanks to the commitment of dedicated members and the ACRL staff.

I am grateful for the support and encouragement that members of the Board have given me in my first year, especially ACRL President Anne Beaubien, who was not only a seasoned and savvy leader, but also caring and thoughtful. I am also grateful for the generosity of the Choice and ACRL staff in giving beyond the call of duty. I look forward eagerly to the year ahead. 


\section{The Year in Review}

Goal 1.

Professional Development.
CONTRIBUTE TO THE TOTAL

PROFESSIONAL DEVELOPMENT OF

ACADEMIC AND RESEARCH LIBRARIANS.

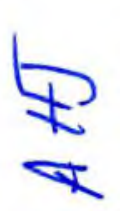

$\mathbf{A}$

total of 2,241 people attended the ACRL Sixth National Conference, "Academic Libraries: Achieving Excellence in Higher Education," April 12-14, 1992, in Salt Lake City, Utah. The conference chair was Joseph A. Boisse', university librarian, University of California, Santa Barbara. Conference attendees rated the conference 3.85 on a 5 -point scale with 5 being excellent. This is the highest evaluation an ACRL National Conference has ever received. The general session speakers included civil rights activist Julian Bond, futurist Paul Saffo, women's studies scholar Catharine Stimpson, and the president of the Council of Library Resources W. David Penniman. In addition to the general session speakers, there were 52 contributed papers, 37 panel presentations, and 31 poster sessions on all areas of academic librarianship.

\section{RBMS Preconference}

ACRL's Rare Books and Manuscripts Section presented a successful three-day conference program at the University of California-Santa Cruz in June 1992. The conference theme for the 33rd RBMSConference, "Scholarly Communication and the Future of Special Collections," provided opportunities for several speakers and presenters to explore issues of electronic publishing, preservation, and information technology with more than 300 attendees.

\section{Annual Conference Programs}

Topics such as recruitment, the virtual library, learning at a distance, accessing African American information resources, medical anthropology, and political correctness were among the 20 programs offered at the ALA Annual Conference. The program "Guts, Brains and Sensitivity or the Ability to Stoop, Lift, and Reach to High Places: What Makes a Good Librarian" reported on current research on career guidance packages and vocational interest inventories. The program "The Virtual Library: The Florida Community College" reported on the creation of a statewide centralized automation project. The Bibliographic Instruction Section and the ALA Library Instruction Round Table sponsored the "15th anniversary of information literacy in ALA- a day-long celebration." (See the next page for a complete list of programs.) 


\section{The Year in Review}

\section{Annual Conference Programs}

- Afro-American Studies Librarians (AFAS)_- Accessing African American Information Resources"

- Anthropology and Sociology (ANSS)_-Medical Anthropology: Choices and Challenges"

- Arts (ARTS)- "Redefining the Arts: Implications for Libraries"

- Bibliographic Instruction (BIS)_- Bulletins from the Recruits: Sharing Information Expertise in the Global Learning Community"

- College Libraries (CLS)_"Alternatives to Collection Ownership: College Library Implications and Applications"

- Community and Junior College Libraries (CJCLS)_._"The Virtual Library: The Florida Community College Experience"

I. Copyright Committee - "Developing and Implementing a Copyright Policy: Institutional Issues for Academic Librarians"

- Education and Behavioral Sciences (EBSS)_-Brief Encounters: Using Techniques from Psychology and Education to Improve the Effectiveness of Reference Service"

n Extended Campus Library Services (ECLSS) - "The Right to Know and Learning at a Distance"

- Law and Political Science (LPSS)_"Voluntary Action, Philanthropy and the Nonprofit Sector: Overview and Resources"

- President's Program-"Prospecting for the Future: How You Can Influence Career Decisions"

- Racial and Ethnic Diversity Committee-_Getting Back to Basics"

- Rare Books and Manuscripts (RBMS)_-Today's Libraries Face Tomorrow's Scholars: Faults and Fissures"

- Research Committee-"Mentoring and Academic Library Research"

- Slavic and East European (SEES)_- "Is There Censorship in the Former Soviet Union?"

- Science and Technology (STS) - "Issues in Sci-Tech Information: Librarians' Right to Know"

- University Libraries (ULS)_- "Views from Across the Quad: The University's Expectations for the Library of the 21st Century"

- Vocational Interest Inventories Task Force-"Guts, Brains and Sensitivity or the Ability to Stoop, Lift and Reach to High Places: What Makes a Good Librarian?"

- Western European Specialists (WESS) _ "Cinema Paradiso: Movies, Libraries, and European Culture"

- Women's Studies (WSS) - "Is the 'Political Correctness' Backlash Controlling Women's Right to Know: Information Suppression in the Information Age 


\section{The Year in Review}

GoAl 2.

\section{ENHANCING}

Service Gapability.
ENHANCE THE CAPABILITY OF

\author{
ACADEMIC AND RESEARCH LIBRAR-
}

IES TO SERVE THE NEEDS OF USERS.

employment conditions. The ACRL Board approved the revised Standards for Faculty Status for College and University Librarians (CERL News, May 1992) and the Model Statement for the Screening and Appointment of Academic Librarians Using a Search Committee (elsewhere in this issue). This year ACRL corresponded with six college and university presidents outlining ALA's position on faculty status for academic librarians. ACRL's Academic Status Committee sponsored a think tank on faculty status at the ALA Midwinter Meeting to explore issues relating to the present and future of faculty status for academic librarians.

ACRL has over 25 published official documents in the form of standards, guidelines, and statements. Standards are policies that describe shared values and principles of performance for a library serving a Carnegie-classified institution. Guidelines consist of procedures that will prove useful in meeting the standards. Statements articulate a policy statement, or serve as a checklist or a model. All official documents are published in CERL News. Over 1,000 reprints were distributed during FY92.

\section{Awards}

ACRL provides a number of opportunities for members to be honored and recognized by colleagues for their work in the profession. The 


\section{The Year in Review}

ACRL Awards program recognizes special achievements and outstanding publications and fosters professional development in academic and research librarianship. This year 12 awards were presented. Member committees review all award nominations and select the winners.

The most prestigious recognition a librarian may receive in the academic library profession is the Academic or Research Librarian of the Year Award. The 1992 award went to Carla Stoffle, dean of libraries at the University of Arizona, Tucson. In choosing Stoffle for this award, the committee noted that "the programs she had been associated with distinguished her in many areas of the library profession, but also earned the respect and admiration of her peers...."

The ACRL Board of Directors presented William $\mathrm{A}$. Moffett (director of the Huntington Library) with a resolution commending him for his dedication and commitment to the library profession. This was most recently exhibited in his courageous act of opening to scholars the Huntington Library's collection of photographs of the Dead Sea Scrolls.

Award winners continued

The Katharine Kyes Leab and Daniel J. Leab American Book Prices Current Exhibition Catalogue Award

Expensive: "Katherine Anne Porter at One Hundred: New Perspectives," submitted by Special Collections, McKeldin Library, University of Maryland; Moderate: "Eric Gill: His Life and Art," submitted by the Thomas Fisher Rare Book Library, University of Toronto; Honorable Mention: "From Palm to Pine: Rudyard Kipling, 1865-1936," submitted by Special Collections, University of Virginia Library

- Martinus NijhoffInternational West European Specialist Study Grant

Martin Antonetti, librarian of The Grolier Club in New York

- Community College Learning Resources Achievement Awards (donated by EBSCO Subscription Services)

Leadership or Community Service: Paul E. Dumont, director of technical services at the Dallas County Community College District in Texas; Program Development: The Library Collection Development Committee at St. Petersburg (Florida) Junior College for the design of procedures for a collection development policy

- ACRL/ALCTS/LAMA/LITA Hugh C. Atkinson Memorial Award

Miriam A. Drake, dean, director of libraries, and professor at the Georgia Institute of Technology in Atlanta 


\section{The Year in Review}

GoAl 3.

\section{Advocacy and Liaison.}

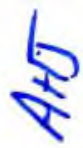

Promote AND SPEAK FOR THE

INTERESTS OF ACADEMIC AND

RESEARCH LIBRARIANSHIP.

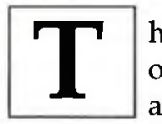

he challenge of recruiting outstanding persons to the field of librarianship and retaining them in the profession can and must be addressed on many fronts. Each year thousands of persons are guided in their selection of a career by the professional profiles drawn in interest inventories and career guidance packages such as the Myers-Briggs Type Indicator (MBTI), the Strong Interest Inventory (SII), and the SIGI PLUS career guidance system. The Vocational Interest Inventories Task Force investigated the profiles of librarians found in these instruments. Each profile was seen as inadequate and/or negative.

By updating the information found in these widely used systems, the task force has made it possible for more persons to get a realistic, dynamic picture of modern librarianship. By negotiating with the publishers of these instruments and interacting with the counselors and advisors who use them, the role of librarians and librarianship is enhanced in the minds of other groups of professionals. We are recruiting tomorrow's librarians today, but we are not in this alone. Many others are in a position to recruit the best and the brightest for us if they are provided the right information. Thanks to the ACRL Vocational Interest Inventories Task Force more people will know that it takes "guts, brains, and sensitivity" to be a good librarian, and fewer will think we need only the ability to "stoop, lift and reach to high places."

Since 1989 the ACRL WHCLIS (White House Conference on Library and Information Services) Task Force has actively engaged in discussions and activities. These discussions ensured that academic librarians' interests were included in the recommendations that formed the national agenda addressing issues of all types of libraries. In addition to the development of a position paper, the chair of the task force participated in two public forums sponsored by NCLIS (National Commission on Libraries and Information Science) to discuss the recommendations and to discuss the National Research and Education Network (NREN). 


\section{The Year in Review}

GoAl 4.

Research \& Publication.

PROMOTE STUDY, RESEARCH, AND PUBLICATION RELEVANT ACADEMIC AND RESEARCH LIBRARIANSHIP.

\section{7 he ACRL University Library Statistics, 1990-91 was released at reports the results of a survey of 120 U.S. libraries at institu-} tions designated as Research Universities I and II and Doctorate Granting Colleges and Universities I and II according to the Carnegie classification and to five Canadian academic libraries with similar scope. The categories of data collected include: collections, personnel, expenditures, and interlibrary loan. The institutional data elements reported include degrees offered, enrollment size, and faculty size.

The Evolving Educational Mission of the Library, published in early spring, was sponsored by the Bibliographic Instruction Section and identifies strategic issues which challenge the development of instructional programs in academic libraries and suggests roles for librarians in the educational processes of their parent institutions.

Women's Studies Collection Development Policies was developed by the Women's Studies Section Collection Development and Bibliography Committee. This unique tool identifies issues and provides models of existing policies. Complete policy statements from 16 university libraries illustrate the range of issues and provide a variety of models. The RLG Conspectus: Women's Studies Supplemental Guideline included as an appendix, identifies issues unique to women's studies and describes materials and sources.

Readers of College $\mathcal{E}$ Research Libraries News

\begin{tabular}{|l}
\hline ACRL Journals \\
Choice \\
Book review journal \\
of ACRL. Eleven is- \\
sues per year (July/ \\
August combined). \\
College \& Research Li- \\
braries \\
Official journal of \\
ACRL. Six bimonthly \\
issues per year. \\
College $\mathcal{E}$ Research Li- \\
braries News \\
Official news maga- \\
zine of ACRL. Eleven \\
issues per year (July/ \\
August combined). \\
Rare Books and Manu- \\
scripts Librarianship \\
A journal of theory \\
and practice covering \\
all aspects of special \\
collections librarian- \\
ship. Two issues per \\
year. \\
\hline
\end{tabular}
have been enthusiastic about the redesign of the magazine. Beginning with the April 1992 issue the magazine has a new, inviting format which readers have called "lively, bold, and easy to read." Other comments include: "At last the magazine has gotten some real style ... It makes getting the magazine a real treat." "Everything from cover to content is appealing. I read it cover to cover as soon as it arrives."

ACRL's sections have led the way in electronic publishing. The Science and Technology Section (STS), the first section involved in electronic publishing, now issues two electronic publications. Electronic 


\section{The Year in Review}

Update appears two weeks before ALA meetings to provide conference-specific information. Issues in Science and Technology Librarianship is STS's electronic journal covering a range of topics such as access, serials pricing, cultural diversity, and virtual libraries. The Afro-American Studies Librarians Section (AFAS), Extended Campus Library Services Section (ECLSS), and Education and Behavioral

\begin{tabular}{|l|}
\hline New Titles from \\
ACRL in 1992 \\
- ACRL University Library \\
Statistics, 1990-91, com- \\
piled by the Library Re- \\
search Center at the Uni- \\
versity of Illinois, Urbana- \\
Champaign \\
- The Evolving Educational \\
Mission of the Library, \\
Betsy Baker and Mary \\
Ellen Litzinger, eds. \\
- Women's Studies Collection \\
Development Policies, a \\
project of the Collection \\
Development and Bibli- \\
ography Committee
\end{tabular}
Sciences Section (EBSS) have all set up electronic listservs on the Internet.

\section{Choice}

Production is the theme that characterized the year for Choice. This was the first year fully operational with the STAR publishing system. All page production was brought in-house and page layout for the magazine and cards is now completed electronically on a sophisticated Macintosh desktop publishing system. The magazine was redesigned to reflect the new publishing venture and to enhance readability.

The Choice reviews database ended pilot projects with CARL Systems and Carnegie Mellon University and will be commercially available for license at the start of the new fiscal year. More than 26,000 reviews, representing four volume years, are available in electronic format.

An Internet account was opened through Princeton University's JvNCNet. Planned use of the network is for reviewer/editor communication and receipt of reviews.

The supplement to the 10th edition of the Guide to Reference Books was published on schedule and announced at ACRL's national conference. Editorial work began on the 11th edition.

Continuing our publication efforts, Choice launched a new series called Ethnic Studies Reviews drawing on titles of an interdisciplinary nature identified in the reviews database. African and African American Studies is the first of the series. In production are Latino Studies, Native American Studies, and Asian American Studies.

Work began on an editorial and publishing plan for Books for Community College Libraries, a work that has not been updated since 1969. 


\section{ACRL Board of Directors, 1991-92}

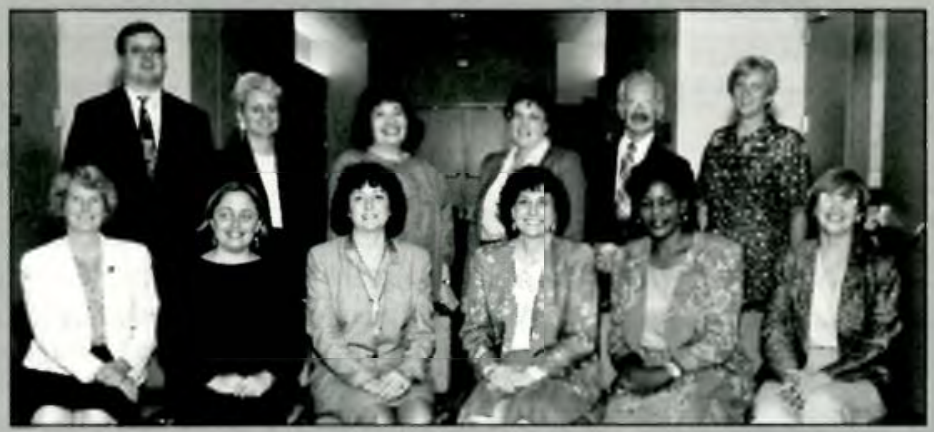

Back row: Ray E. Metz, Barbara J. Wittkopf, Rochelle Sager, Eileen Dubin, Evan Ira Farber, Shelley E. Phipps. Front row: Leslie A. Manning, Barbara J. Ford, Jacquelyn A. McCoy, Anne K. Beaubien, Althea Jenkins, Karin E. Begg. Not shown: Linda Phillips.

\section{ACRL Board of Directors, 1991-92}

- President:

Anne K. Beaubien, University of Michigan

- Vice-President/President-Elect: Jacquelyn A. McCoy, Occidental College

- Past-President: Barbara J. Ford, Virginia Commonwealth University

- Budget $\mathcal{E}$ Finance Committee Chair: Leslie A. Manning, University of Colorado at Colorado Springs

- Executive Director (ex-officio): Althea H. Jenkins, ACRL /ALA

- ACRL Councilor: Rochelle Sager, Fashion Institute of Technology

Directors-at-Large:

- Karin E. Begg, Boston College

- Eileen Dubin, Case Western Reserve University

- Evan Ira Farber, Earlham College

- Ray E. Metz, Case Western Reserve University

- Linda L. Phillips, University of Tennessee

- Shelley E. Phipps, University of Arizona

- Barbara J. Wittkopf, Louisiana State University 


\section{Financial Report}

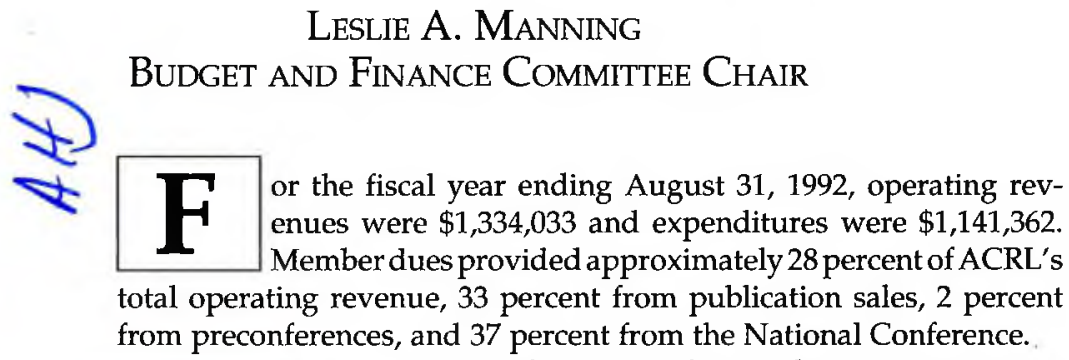

ACRL administers five endowment accounts.

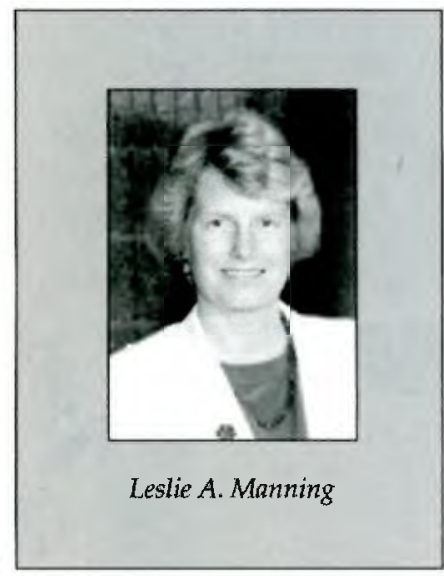
Threeendowments-Hugh Atkinson Memorial, Oberly, and Leab - support the awards named. A fourth endowment was approved by the ACRL Board and established by ALA in December 1991. The Board will determine annually how the income from this endowment will be used. On August 31,1992, the principle in these accounts totaled $\$ 89,801$. The fifth endowment for Choice has a principle of $\$ 20,641$.

Among expenditures in the general fund, member services comprised 33 percent of ACRL's total expenses. Other expenses include publications (37 percent), the National Conference ( 28 percent), and preconferences ( 2 percent).

Revenue was less than budgeted by $\$ 58,382$, but due to excellent cost containment by staff, expenses were $\$ 194,721$ less than budgeted, leaving a balance of $\$ 192,671$ in revenues above expenses. At the close of the fiscal year, the "Operating Fund Balance" stood at $\$ 614,036$ which will fully cover the "mandated reserve" as well as provide necessary planning dollars for the Seventh National Conference in Pittsburgh.

Choice ended the year with $\$ 37,425$ in net revenue. The Choice

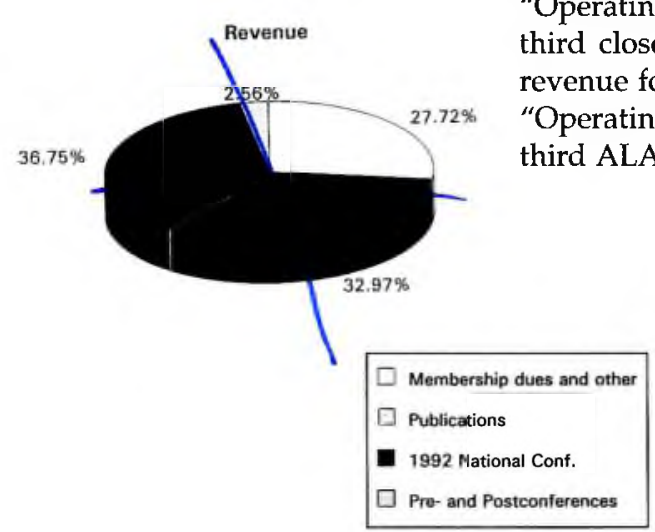
"Operating Fund Balance" stood at $\$ 764,662$ at the third close. The combined ACRL and Choice net revenue for FY 1992 was $\$ 230,096$. The combined "Operating Fund Balance" was $\$ 1,378,698$ at the third ALA close.

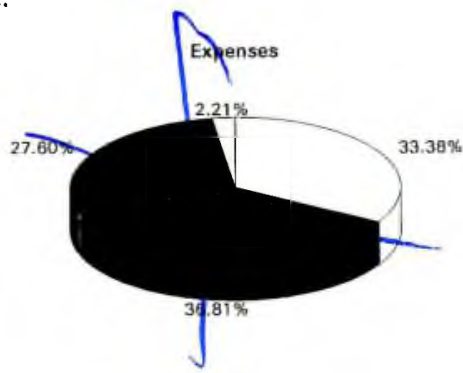




\section{Financial Report}

\section{Executive Summary 1991-92}

\begin{tabular}{|c|c|c|c|c|}
\hline SOURCES OF REVENUE & $\begin{array}{c}\text { FY1992 } \\
\text { BUDGET }\end{array}$ & $\begin{array}{l}\text { FY1992 } \\
\text { ACTUAL } \\
\end{array}$ & $\begin{array}{c}\text { PERCENT } \\
\text { OF BUDGET }\end{array}$ & $\begin{array}{c}\text { LAST YEAR } \\
\text { ACTUAL }\end{array}$ \\
\hline $\begin{array}{l}\text { Ending Reserve } \\
\text { Aug. } 31 \text { : Op. Fund } \\
\text { Aug. } 31: \text { Endowment } \\
\text { Aug. } 31 \text { : Choice }\end{array}$ & $\begin{array}{r}\$ 410,938 \\
\$ 80,275 \\
\$ 711,999\end{array}$ & $\begin{array}{r}\$ 614,036 \\
\$ 89,801 \\
\$ 764,662\end{array}$ & $\begin{array}{l}149.42 \% \\
111.87 \% \\
107.40 \%\end{array}$ & $\begin{array}{r}\$ 516,586 \\
\$ 67,783 \\
\$ 795,581\end{array}$ \\
\hline Subtotal & $\$ 1,203,212$ & $\$ 1,468,499$ & $122.05 \%$ & $\$ 1,379,950$ \\
\hline $\begin{array}{l}\text { Membership dues and other } \\
\text { Other } \\
\text { Advisory } \\
\text { Awards } \\
\text { Jobline }\end{array}$ & $\begin{array}{r}\$ 400,095 \\
\$ 600 \\
\$ 500 \\
\$ 1,500 \\
\$ 3,350\end{array}$ & $\begin{array}{r}\$ 353,184 \\
\$ 12,165 \\
\$ 0 \\
\$ 1,160 \\
\$ 1,201\end{array}$ & $\begin{array}{r}88.28 \% \\
2027.50 \% \\
0.00 \% \\
77.33 \% \\
35.85 \%\end{array}$ & $\begin{array}{r}\$ 351,262 \\
\$ 4,930 \\
\$ 0 \\
\$ 650 \\
\$ 3,260\end{array}$ \\
\hline Subtotal & $\$ 406,045$ & $\$ 367,710$ & $90.56 \%$ & $\$ 360,102$ \\
\hline $\begin{array}{l}\text { Publications } \\
\text { Choice } \\
\text { C\&RL } \\
\text { C\&RLNews } \\
\text { RBML } \\
\text { Sec. Newsletters } \\
\text { Nonperiodical Pubs. } \\
\text { BCL } \\
\text { Chapter Topics }\end{array}$ & $\begin{array}{r}\$ 1,587,965 \\
\$ 134,831 \\
\$ 237,326 \\
\$ 20,460 \\
\$ 50 \\
\$ 64,500 \\
\$ 3,500 \\
\$ 0\end{array}$ & $\begin{array}{r}\$ 1,455,913 \\
\$ 117,038 \\
\$ 223,970 \\
\$ 24,031 \\
\$ 16 \\
\$ 69,381 \\
\$ 2,932 \\
\$ 0\end{array}$ & $\begin{array}{r}91.68 \% \\
86.80 \% \\
94.37 \% \\
117.45 \% \\
32.00 \% \\
107.57 \% \\
83.77 \% \\
0.00 \%\end{array}$ & $\begin{array}{r}\$ 1,418,488 \\
\$ 121,451 \\
\$ 223,323 \\
\$ 18,330 \\
\$ 18 \\
\$ 82,320 \\
\$ 12,375 \\
\$ 0\end{array}$ \\
\hline Subtotal & $\$ 2,048,632$ & $\$ 1,893,281$ & $92.42 \%$ & $\$ 1,876,305$ \\
\hline $\begin{array}{l}\text { Education } \\
\text { Continuing Ed. } \\
\text { National }(89,92) \\
\text { Pre-\& Postconferences }\end{array}$ & $\begin{array}{r}\$ 0 \\
\$ 467,963 \\
\$ 51,308\end{array}$ & $\begin{array}{r}\$ 285 \\
\$ 487,489 \\
\$ 33,892\end{array}$ & $\begin{array}{r}104.17 \% \\
66.06 \%\end{array}$ & $\begin{array}{r}\$ 17,689 \\
\$ 0 \\
\$ 51,405\end{array}$ \\
\hline Subtotal & $\$ 519,271$ & $\$ 521,666$ & $100.46 \%$ & $\$ 69,094$ \\
\hline $\begin{array}{l}\text { Funded Projects } \\
\text { NEH/HBCU Project } \\
\text { HBCU Statistics (Mellon) }\end{array}$ & $\begin{array}{r}\$ 6,432 \\
\$ 0\end{array}$ & $\begin{array}{r}\$ 0 \\
\$ 7,289\end{array}$ & $\begin{array}{r}0.00 \% \\
113.32 \%\end{array}$ & $\begin{array}{r}\$ 9,212 \\
\$ 0\end{array}$ \\
\hline Subtotal & $\$ 6,432$ & $\$ 7,289$ & $113.32 \%$ & $\$ 9,212$ \\
\hline $\begin{array}{l}\text { TOTALREVENUE } \\
\text { Choice Revenue }\end{array}$ & $\begin{array}{l}\$ 2,980,380 \\
\$ 1,587,965\end{array}$ & $\begin{array}{l}\$ 2,789,946 \\
\$ 1,455,913\end{array}$ & $\begin{array}{l}93.61 \% \\
91.68 \%\end{array}$ & $\begin{array}{l}\$ 2,314,713 \\
\$ 1,418,488\end{array}$ \\
\hline TOTAL REV. W/O CHOICE & $\$ 1,392,415$ & $\$ 1,334,033$ & $95.81 \%$ & $\$ 896,225$ \\
\hline
\end{tabular}




\section{Financial Report}

\begin{tabular}{lrrrr}
\hline OBJECT OF EXPENSE & $\begin{array}{r}\text { FY1992 } \\
\text { BUDGET }\end{array}$ & $\begin{array}{r}\text { FY1992 } \\
\text { ACTUAL }\end{array}$ & $\begin{array}{c}\text { PERCENT } \\
\text { OF BUDGET }\end{array}$ & $\begin{array}{r}\text { LASTYEAR } \\
\text { ACTUAL }\end{array}$ \\
\hline Membership Activities & & & & \\
Membership Svcs. & $\$ 55,277$ & $\$ 41,939$ & $75.87 \%$ & $\$ 40,433$ \\
Exec. Comm. \& Board & $\$ 83,797$ & $\$ 71,950$ & $85.86 \%$ & $\$ 64,437$ \\
Statistics & $\$ 13,803$ & $\$ 13,303$ & $96.38 \%$ & $\$ 3,191$ \\
Advisory & $\$ 24,835$ & $\$ 21,837$ & $87.93 \%$ & $\$ 32,130$ \\
Standards distrib. & $\$ 7,247$ & $\$ 4,595$ & $63.41 \%$ & $\$ 4,626$ \\
Discussion Groups & $\$ 4,812$ & $\$ 4,266$ & $88.65 \%$ & $\$ 3,734$ \\
Awards & $\$ 11,218$ & $\$ 10,027$ & $89.38 \%$ & $\$ 15,802$ \\
Chapters & $\$ 58,588$ & $\$ 44,454$ & $75.88 \%$ & $\$ 41,314$ \\
Committees & $\$ 71,439$ & $\$ 54,574$ & $76.39 \%$ & $\$ 50,685$ \\
Sections & $\$ 64,461$ & $\$ 59,039$ & $91.59 \%$ & $\$ 43,490$ \\
Jobline & $\$ 2,564$ & $\$ 2,251$ & $87.79 \%$ & $\$ 4,038$ \\
Section Newsletters & $\$ 37,032$ & $\$ 30,050$ & $81.15 \%$ & $\$ 33,575$ \\
Chapter Topics & $\$ 5,134$ & $\$ 5,125$ & $99.82 \%$ & $\$ 4,523$ \\
C\&RLNews & $\$ 21,370$ & $\$ 14,977$ & $70.08 \%$ & $\$ 63,267$ \\
\hline Subtotal & $\$ 461,577$ & $\$ 378,387$ & $81.98 \%$ & $\$ 405,245$ \\
\hline Publications & & & & \\
Choice & & & & \\
C\&RL & $\$ 1,563,203$ & $\$ 1,418,488$ & $90.74 \%$ & $\$ 1,550,610$ \\
C\&RL News & $\$ 134,741$ & $\$ 109,338$ & $81.15 \%$ & $\$ 112,751$ \\
RBML & $\$ 237,326$ & $\$ 223,970$ & $94.37 \%$ & $\$ 286,590$ \\
Nonperiodical Pubs. & $\$ 20,703$ & $\$ 16,055$ & $77.55 \%$ & $\$ 23,573$ \\
BCL & $\$ 52,103$ & $\$ 67,381$ & $129.32 \%$ & $\$ 39,018$ \\
\hline Subtota & $\$ 2,879$ & $\$ 520$ & $18.06 \%$ & $\$ 2,955$ \\
\hline
\end{tabular}

$\begin{array}{lllll}\text { Subtotal } & \$ 2,010,955 & \$ 1,835,752 & 91.29 \% & \$ 2,015,497\end{array}$

\section{Special Projects}

Output Measures

$\$ 0$

$\$ 0.00 \%$

$\$ 1,855$

Special Grants Funds

$\$ 0 \quad \$ 0$

$\$ 11,138$

\begin{tabular}{lrrrr}
\hline Subtotal & $\$ 0$ & $\$ 0$ & $0.00 \%$ & $\$ 12,993$ \\
\hline Education & & & & \\
Continuing Ed. & $\$ 0$ & $\$ 362$ & $0.00 \%$ & $\$ 49,955$ \\
National (89, 92) & $\$ 364,469$ & $\$ 312,955$ & $85.87 \%$ & $\$ 63,584$ \\
Pre-\& Postconferences & $\$ 55,853$ & $\$ 25,105$ & $44.95 \%$ & $\$ 52,207$ \\
\hline Subtotal & $\$ 420,322$ & $\$ 338,422$ & $80.51 \%$ & $\$ 165,746$ \\
\hline
\end{tabular}

Funded Projects

\begin{tabular}{lrrrr} 
HBCU Statistics (Mellon) & $\$ 6,432$ & $\$ 7,289$ & $113.32 \%$ & $\$ 0$ \\
\hline \multicolumn{1}{c}{ Subtotal } & $\$ 6,432$ & $\$ 7,289$ & $113.32 \%$ & $\$ 0$ \\
\hline TOTAL EXPENSES & $\$ 2,899,286$ & $\$ 2,559,850$ & $\mathbf{8 8 . 2 9 \%}$ & $\$ 2,599,481$ \\
Choice Expenses & $\$ 1,563,203$ & $\$ 1,418,488$ & $90.74 \%$ & $\$ 1,550,610$ \\
TOTAL EXP. W/O CHOICE & $\$ 1,336,083$ & $\$ 1,141,362$ & $\mathbf{8 5 . 4 3 \%}$ & $\$ 1,048,871$ \\
\hline NET & $\$ 56,332$ & $\$ 192,671$ & $\mathbf{3 4 2 . 0 3 \%}$ & $\mathbf{( \$ 1 5 2 , 6 4 6 )}$ \\
\hline
\end{tabular}




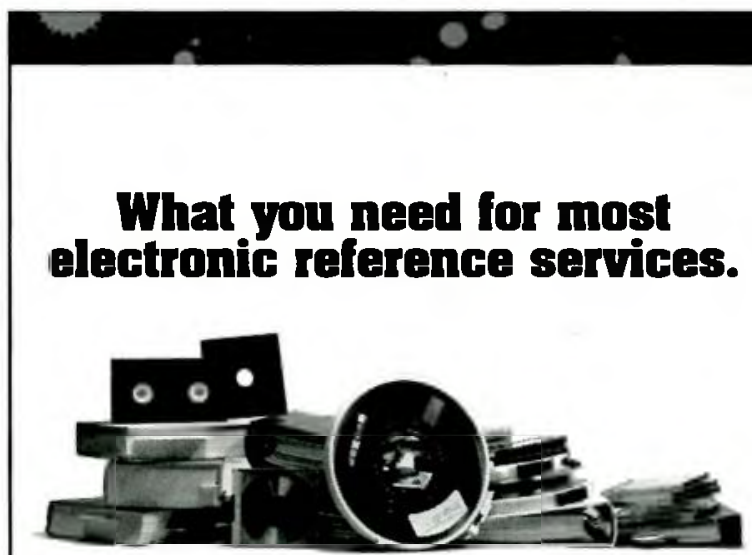

\section{What you need for Firstsearch.}

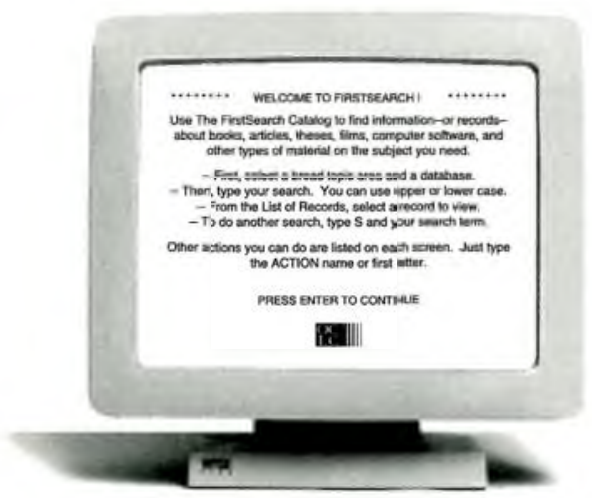

Hils seanch Libraries have lots of

options for providing reference databases to their patrons. None are as simple and as effective as The FirstSearch Catalog.

FirstSearch is ...

- An online service with 25 databases. Some are your patrons' favorites. Some, like WoridCat (the ocLC Online Union Catalog) are available nowhere else. And some, like Readers' Guide, include OCLC holdings symbols. And more databases will be added regularly—at no charge to you.

- A service easy enough for your patrons to use without special training. Powerful enough to find information they need. And accessible in the library or from remote locations.

- A service that requires little capital investment and computer knowledge. You use existing equipment. And you administer the service with existing staff. Computer specialists are not needed.

With FirstSearch, there's no extra furniture or hardware to buy. No lines of patrons waiting to use a terminal. No complicated networks or software to install. No databases to load. No computer storage to buy. No new employees to hire.

All you do is subscribe.

\section{Complicated Ghoices. The Simple Solution. \\ Firstsearch.}

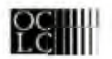

U.S. and Cmnada (aOO) R4a-5878 Ohio (ano) 849-8286

OCLC...for today's libraries 